\title{
THE PERSPECTIVES OF ISLAMIC SCHOLARS \\ ON RELIGIOUS DERADICALIZATION AND SOCIAL MEDIA ROLES
}

\author{
M Nurul Ikhsan Saleh \\ Universitas Islam Indonesia \\ Sleman, Yogyakarta, Indonesia \\ E-mail:mnurul.ikhsan.saleh@uii.ac.id \\ Yuli Astiana \\ The University of Adelaide \\ Adelaide, South Australia, Australia \\ E-mail:yuli.astiana@adelaide.edu.au
}

\begin{tabular}{c|c|c}
\hline Received: & Revised: & Approved: \\
23/08/2021 & $22 / 10 / 2021$ & $13 / 12 / 2021$ \\
\hline
\end{tabular}

DOI : 10.32332/akademika.v26i2.3565

\begin{abstract}
Tackling religious radicalism is a challenge in Indonesia which acts of intolerance, group exclusion, religion-based violence, terrorism, and hate speech through social media occur repeatedly. This study aims to explore the perceptions of Islamic scholars in Yogyakarta regarding the deradicalization of religion and the role of social media in religious deradicalization. This research uses a case study method which is part of qualitative research. Researchers collected data by conducting in-depth interviews via offline or online interviews through the Zoom application. Participants were 16 male and female Islamic scholars coming from various backgrounds of Islamic organizations, such as Muhammadiyah, Nahdlatul Ulama, the Indonesian Islamic Da'wah Institute, Hizbut Tahrir Indonesia, and the Qur'an Tafsir Council. The location of this research is Yogyakarta Special Region. Interview data were analyzed using thematic analysis methods. This study of religious deradicalization found four major themes, namely strengthening awareness of being Indonesia, prioritizing an inclusive approach as a soft approach in fighting radicalism, promoting a deep understanding of Islam, and utilizing social media. This research provides a novel finding that could contribute to the government, religious leaders, educational institutions, and The National Counter Terrorism Agency where religious deradicalization programs need to be focused on a soft approach, involving the use of social media, targeting blind spot areas such as study programs of medical, engineering, and pharmacy at universities and ensuring mosques uncontrolled by radical groups.
\end{abstract}

Keywords: Religious deradicalization, islamic scholars, and social media

\section{A. Introduction}

The religious radicalism that has developed in Indonesia and has allegedly led to the emergence of radicalism, terrorism, and religious-based organizations that promote violence cannot be separated from the involvement of religious leaders or scholars. One of the religious figures who emerged was Abu Bakar Basyir as the 
leader of the Jemaah Islamiah organization which was considered to have intersected with the emergence of terrorists such as the Bali Bombing in 2002 and the Marriott Hotel Jakarta Bombing in 2003. ${ }^{1}$ Other Islamic scholars associated with radical religious organizations were Abdullah Sungkar and Ja'far Umar Thalib. ${ }^{2}$ However, the existence of Islamic scholars could be a means of de-radicalization, one example is the promotion of moderate Islam by Islamic scholars who are members of the Nahdlatul Ulama organization. ${ }^{3}$ Therefore, a research in the field of religious deradicalization is relevant to be studied as part of an effort to counter religious radicalism.

Several studies have been conducted on the de-radicalization of religion. One of the studies related to religious deradicalization has been carried out by Farida and Kasdi using the method of literature review, observation, and interviews where this research examined the role of female Muslim scholars in promoting the social transformation movement after the Indonesian Women's Ulama Congress in 2017. This study found that the role of women is marginalized even though, on the other hand, studies related to gender and women are increasingly being carried out. However, female Muslim scholars have struggled a lot in fighting against injustice against women. They have become part of a driving force in responding to humanitarian issues, promoting moderate Islam, and fighting for equality between the roles of men and women. ${ }^{4}$

The second research was conducted by Latief and Nashir where Nashir himself is the leader of the second-largest Islamic organization in Indonesia, Muhammadiyah. This study presented that the Muhammadiyah organization has taken part in the process of deradicalization or more generally in peace actions during the last thirty years through some of its activities such as promoting the purity of Islam by returning to adhering to the Quran and Hadith and participating in national and international humanitarian activities such as social assistance for all groups. ${ }^{5}$

The third deradicalization study was conducted by Yaoren, where the study showed that the de-radicalization of religion by killing or imprisoning the leaders of religious terrorist organizations was considered ineffective because this resulted in the revenge mobilization from terrorists groups whose leaders were punished and carried out counter-attacks. Law enforcement agencies seem to need another strategy in breaking the chain of religious radicalism and terrorism networks. ${ }^{6}$ Another study conducted by Horgan and Braddock stated that the research on the effectiveness of the deradicalization program that has been carried out recently is still relatively

${ }^{1}$ Kenneth Yeo Yaoren, "Leadership Decapitation and the Impact on Terrorist Groups," Counter Terrorist Trends and Analyses 11, no. 3 (2019): 7-12.

2 Adib Rifqi Setiawan, "Islamic Education in Southeast Asia," 2020, https://edarxiv.org/dnjqv/.

3 Alexander Raymond Arifianto, "Islam Nusantara: NU's Bid to Promote 'Moderate Indonesian Islam,'” 2016.

${ }^{4}$ Umma Farida and Abdurrohman Kasdi, "The 2017 KUPI Congress and Indonesian Female 'Ulama," Journal of Indonesian Islam (JIIS) 12, no. 02 (2018): 135-58,.

${ }^{5}$ Hilman Latief and Haedar Nashir, "Local Dynamics and Global Engagements of the Islamic Modernist Movement in Contemporary Indonesia: The Case of Muhammadiyah (20002020)," Journal of Current Southeast Asian Affairs, 2020, 1868103420910514, https://doi.org/10.1177/1868103420910514.

6 Yaoren, "Leadership Decapitation and the Impact on Terrorist Groups." 
limited. ${ }^{7}$

Meanwhile, research on deradicalization concerning social media has also been conducted by several researchers. The first research was conducted by Dean and Bell who looked into the negative side of social media. They said that social media has been used as a platform for spreading radicalism by terrorist groups or what is known as "online terrorism". The study using this literature broadly categorizes three social media carried out by terrorist groups; firstly, Facebook as a social media application for recruitment; secondly, Twitter as a technology for posting information and communicating media; thirdly, YouTube as information technology for training terrorist members. ${ }^{8}$

Another study conducted by Tsesis related to the role of social media in carrying out terrorist propaganda and recruitment by terrorist organizations. In particular, Tsesis examined the Communications Compliance Act in the United States in response to the use of social media for radicalism or terrorism activities. The researcher concluded that the law was good enough to deter a person or organization from creating an online-based platform for disseminating information or material related to terrorist propaganda. ${ }^{9}$

Furthermore, the next research was carried out by Weimann where the research was presented in 2003. It was found that there were more than 2,600 websites linked to terrorist organizations and in 2007 the number increased to nearly 6,000 websites that were considered to be sponsors and support for the terrorist movement around the world. The researcher then concluded that terrorist members not only fought in the real world but also fought through cyberspace or social media. Unfortunately, the awareness of many people about the dangers posed by the dissemination of information by terrorist networks is still considered very small. Another problem encountered is related to tracking website managers who are networked with terrorist groups where website makers use anonymous identities. ${ }^{10}$ This can be understood that social media is a threat because everyone can publish contents which do not only access information contents. Therefore, terrorist groups can freely produce content widely to be enjoyed by the wider community. One example, Salafi militant networks such as al-Qaeda in 2008 had used Facebook as recruitment or seeking participants. ${ }^{11}$

From the studies on the use of social media as the spread of radicalism by terrorist groups mentioned above, the researchers understand that the spread of religious radicalism and terrorism through social media will be a serious threat not only to Indonesia but to the global community due to the emergence of websites created by the terrorist group that can be done anytime and anywhere. Moreover, the number of social media users of young people and students is increasing in Indonesia. This allows the users who are young and who do not yet have a good

7 John Horgan and Kurt Braddock, "Rehabilitating the Terrorists?: Challenges in Assessing the Effectiveness of de-Radicalization Programs," Terrorism and Political Violence 22, no. 2 (2010): 267-91, https:/ / doi.org/10.1080/09546551003594748.

8 Geoff Dean and Peter Bell, "The Dark Side of Social Media: Review of Online Terrorism," Pakistan Journal of Criminology 3, no. 4 (2012): 191-210, https://eprints.qut.edu.au/50162/.

9 Alexander Tsesis, "Social Media Accountability for Terrorist Propaganda," Fordham L. Rev. 86 (2017): 605.

${ }^{10}$ Gabriel Weimann, Terror on the Internet: The New Arena, the New Challenges (US Institute of Peace Press, 2006).

11 Murad Batal Al-Shishani, "Taking Al-Qaeda's Jihad to Facebook," The Jamestown Foundation: Terrorism Monitor 8, no. 5 (2010): 3. 
understanding, to be targeted by terrorist networks with religious radicalism to be recruited or influenced as terrorists under the guise of religion.

The researchers conclude that there are still gaps in studies that focus on the deradicalization of religion through social media from the perspective of Islamic scholars with varied theological backgrounds, particularly research conducted in Indonesia, based on existing literature and research. As a result, the researchers believe that it is critical to research the deradicalization of religion through social media from the perspective of Islamic scholars to fill the research gap and provide input to policymakers, educators, and religious stakeholders to contribute to the creation of peace and nonviolent religious understanding not only for the Indonesian people but also for the international community.

This research focuses on the study of deradicalization through social media from the perspective of Islamic scholars. This study has a few similarities with previous studies, such as the same research related to the deradicalization of religion. However, this research is certainly different from the research conducted by Altier et al, which focuses on the reasons for stopping someone from being a terrorist who has committed a crime and then leaves a certain religious movement. ${ }^{12}$ Another study examines the reasons a person joins extreme militant religious groups. ${ }^{13}$ This research specifically focuses on deradicalization studies from the perspective of both male and female Muslim scholars. The novelty of this research lies in how the views of the ulama are related to the role of social media in religious radicalization, which is expected to have a major impact against religious radicalism or terrorism movements in Indonesia.

Although the study of religious deradicalization can be studied from the perspective of many different religions in Indonesia, this research only focuses on studies from the perspective of Muslim scholars. To focus on this research study, one research question is on how the perceptions of Islamic scholars in Yogyakarta regarding the deradicalization of religion and the role of social media in the deradicalization of religion. The researchers consider that the process of religious deradicalization is not sufficient only through the making of laws or through fighting against terrorism with law enforcement involving the police or the army. The process of deradicalization requires the involvement of the thoughts of Islamic scholars whose opinions can be heard and followed by the congregation at large. The researchers consider that this research is very valuable not only for research development, but the results of this research are also expected to provide valuable input for actors in the field of religion, policymakers, the world of education, and the wider community in their efforts to deradicalize religion in Indonesia so that people live in peace.

This research uses a type of case study which is part of qualitative research. Researchers chose in-depth interviews in collecting data by involving 16 participants consisting of male and female Muslim scholars who are affiliated with various religious organizations. The age range of participants is 23 to 65 years old with the requirement that they have given Islam-related speeches or sermons in mosques, and

12 Mary Beth Altier, Christian N Thoroughgood, and John G Horgan, "Turning Away from Terrorism: Lessons from Psychology, Sociology, and Criminology," Journal of Peace Research 51, no. 5 (2014): 647-61, https:/ / doi.org/10.1177/0022343314535946.

13 Tore Bjørgo, "Dreams and Disillusionment: Engagement in and Disengagement from Militant Extremist Groups," Crime, Law and Social Change 55, no. 4 (2011): 277-85, https://link.springer.com/article/10.1007/s10611-011-9282-9. 
that they have experience propagating Islamic issues using social media or that their lectures have been uploaded to social media. Questions were given to participants in the form of open-ended questions. Researchers chose in-depth interviews to obtain essential types of data, new insights from participants' perspectives, ${ }^{14}$ and deep understanding or experience. ${ }^{15}$ There are at least six stages in thematic analysis, namely; (1) familiarize oneself with the data, (2) categorize data into sub-categories, (3) find suitable themes, (4) evaluate existing themes, (5) label themes, and (6) produce data in reports. ${ }^{16}$ The following table below is the demographic data of participants in this study.

Table 1. Participant's demographic data

\begin{tabular}{|c|c|c|c|c|}
\hline Pseudonym & $\begin{array}{c}\text { Age } \\
\text { (years) }\end{array}$ & Gender & $\begin{array}{c}\text { Islamic } \\
\text { Organization/Movement }\end{array}$ & Roles \\
\hline Munsif & 38 & Male & Nahdlatul Ulama (NU) & $\begin{array}{l}\text { Secretary at } \\
\text { PWNU }\end{array}$ \\
\hline Kamil & 59 & Male & Muhammadiyah & $\begin{array}{c}\text { Member of } \\
\text { Tabligh } \\
\text { Assembly }\end{array}$ \\
\hline Mansur & 65 & Male & Nahdlatul Ulama (NU) & Mustasya \\
\hline Jasmin & 63 & Female & Muhammadiyah & $\begin{array}{l}\text { Member of } \\
\text { Majelis Tarjih }\end{array}$ \\
\hline Iqbal & 65 & Male & $\begin{array}{c}\text { Muhammadiyah }+ \\
\text { Nahdlatul Ulama (NU) }\end{array}$ & Preacher \\
\hline Rania & 49 & Female & Muhammadiyah & $\begin{array}{c}\text { Member of } \\
\text { Tarjih and } \\
\text { Taidid Council }\end{array}$ \\
\hline Husain & 52 & Male & Muhammadiyah & $\begin{array}{l}\text { Member of } \\
\text { Education } \\
\text { Council }\end{array}$ \\
\hline Diwan & 47 & Male & Salafi Movement & Preacher \\
\hline Karim & 57 & Male & Nahdlatul Ulama (NU) & $\begin{array}{c}\text { Leader of } \\
\text { Islamic Boarding } \\
\text { School }\end{array}$ \\
\hline Samir & 60 & Male & $\begin{array}{l}\text { Lembaga Dakwah Islam } \\
\text { Indonesia (LDII)/ the } \\
\text { Indonesian Islamic } \\
\text { Da'wah Institute }\end{array}$ & $\begin{array}{l}\text { Steering } \\
\text { Committee }\end{array}$ \\
\hline Pasha & 63 & Male & $\begin{array}{l}\text { Lembaga Dakwah Islam } \\
\text { Indonesia (LDII)/ the } \\
\text { Indonesian Islamic } \\
\text { Da'wah Institute }\end{array}$ & $\begin{array}{c}\text { Leader at } \\
\text { District Areas }\end{array}$ \\
\hline
\end{tabular}

14 Robert K Yin, "Case Study Research and Applications" (Sage, 2018), http://dln.jaipuria.ac.in:8080/jspui/bitstream/123456789/1615/1/Case study research and applications design and methods by Campbell\%2C Donald Thomas Yin\%2C Robert K..pdf.

15 Helena Harrison et al., "Case Study Research: Foundations and Methodological Orientations," in Forum Qualitative Sozialforschung/Forum: Qualitative Social Research, vol. 18, 2017.

16 Virginia Braun and Victoria Clarke, "Using Thematic Analysis in Psychology," Qualitative Research in Psychology 3, no. 2 (2006): 77-101. 


\begin{tabular}{ccccc}
\hline Pseudonym & $\begin{array}{c}\text { Age } \\
\text { (years) }\end{array}$ & Gender & $\begin{array}{c}\text { Islamic } \\
\text { Organization/Movement }\end{array}$ & Roles \\
\hline Jamal & 58 & Male & Muhammadiyah-PKS & Syuro Council \\
Nasif & 23 & Male & Islamic Boarding School & Preacher \\
Maryam & 38 & Female & $\begin{array}{c}\text { HTI (Hizbut Tahrir } \\
\text { Indonesia) }\end{array}$ & Preacher \\
Sadiq & 55 & Male & $\begin{array}{c}\text { Lembaga Dakwah Islam } \\
\text { Indonesia (LDII)/ the } \\
\text { Indonesian Islamic } \\
\text { Da'wah Institute } \\
\text { Majelis Tafsir Alquran } \\
\text { (MTA)/ the Qur'an } \\
\text { Tafsir Council }\end{array}$ & $\begin{array}{c}\text { Leader at DPP } \\
\text { Regional Areas }\end{array}$ \\
\hline
\end{tabular}

The interview duration in data collection ranged from thirty minutes to two hours in a face-to-face manner in which the interviews were recorded. Some participants have chosen to use online interviews via the Zoom application platform. Participants were given two options to choose the interview model whether through the Zoom application or face-to-face interviews. This method was taken to avoid the spread of Covid-19. Meanwhile, in face-to-face interviews, researchers applied strict health protocols according to applicable regulations to maintain the safety of participants and researchers. The research location is in the Special Region of Yogyakarta. The reason for choosing the location of Yogyakarta is because it is a multicultural area or as a miniature of the Indonesian state. In addition, it is also because of the existence of various Islamic organizations in Yogyakarta. ${ }^{17}$ The participants interviewed were affiliated with the following Islamic organizations or movements: Nahdlatul Ulama, the Salafi Movement, Muhammadiyah, Yogyakarta Islamic Boarding School, the Indonesian Islamic Da'wah Institute, and the Qur'an Tafsir Council.

This research specifically examined the views and attitudes of Islamic scholars in Indonesia, especially in Yogyakarta concerning the deradicalization of religion in countering radicalism. The Islamic scholars in question are among the Muslim scholars. Furthermore, the researchers also explored the views of these scholars regarding the role of social media in efforts to deradicalize religion. Researchers see that the use of social media in Indonesia is massive. Therefore, deradicalization efforts through social media are considered very valuable to be carried out to counteract radicalism that leads to acts of terrorism and religion-based violence.

The important keywords in the discussion of this research are deradicalization, social media, and Islamic scholars. In contrast to radicalism, deradicalization is defined as the process of a person fighting an ideology that was previously championed, which is marked by a change in behavior to stop embracing a radical understanding that promotes violence. ${ }^{18}$ Furthermore, social media is interpreted as an internet-based application technology from Web 2.0. Social media is generally divided into several parts, namely social media formed based on group work such as

17 Halimah Lubis, "Model Dakwah LDII Yogyakarta Dalam Penguatan Kerukunan Umat Beragama (Ditinjau Dari Perspektif Manajemen Dakwah)," Tadbir: Jurnal Manajemen Dakwah FDIK IAIN Padangsidimpuan 2, no. 1 (2020): 23-48.

18 Bertjan Doosje et al., “Terrorism, Radicalization and de-Radicalization," Current Opinion in Psychology 11 (2016): 79-84, https:/ / doi.org/10.1016/j.copsyc.2016.06.008. 
Wikipedia, content-based community social media such as Youtube, social networking sites such as Facebook, and virtual games such as World of Warcraft. ${ }^{19}$ The purpose of social media itself can be for communication, establishing relationships with other people, and exchanging information. ${ }^{20}$ In several recent studies, this is believed that social media has increased the socialization of human activities in everyday life. ${ }^{21}$ Kaplan and Haenlein mentioned several characteristics of social media, namely the virtual social world, the world of virtual games, social networking sites, community-based content, blogs, and collaborative projects. ${ }^{22}$ Meanwhile, the meaning of Islamic scholars is closer to the definition of being aware and knowledgeable. It is more like Gilliot's definition in this research, namely persons who are specialists in the religious sector, particularly comprehending Islamic law and doctrine. ${ }^{23}$

There are four major themes in the research results and discussion in response to the research question of how the deradicalization of religion and the role of social media in the perspective of scholars. The four themes are strengthening awareness of being Indonesian, promoting an inclusive approach, promoting a deep understanding of Islam, and optimizing the roles of social media in the deradicalization of religion.

\section{B. Strengthening Awareness of Being an Indonesian Person}

Deradicalization of religion in Indonesia needs to be pursued by building awareness to become a person who understands Indonesia where this awareness itself is supported by religion. It is important to prioritize Indonesia's interests rather than merely group interests, such as Islamic groups. Mansur as a mustasyar in the Islamic organization Nahdlatul Ulama explains the importance of awareness of being a person who loves Indonesia. ${ }^{24}$

Several other participants also expressed the importance of building awareness of being Indonesian. There are at least four aspects that can be applied as efforts to develop self-awareness to become Indonesian. The four aspects are 1) understanding the harmony between Pancasila and Islam, 2) building a spirit of nationalism, 3) understanding Islam as a value, not a system, and 4) understanding that the caliphate is not a solution to the problems faced by Indonesia.

\section{The suitability of Pancasila and Islam}

One of the efforts to build this awareness is to provide awareness that Pancasila is the ideology of the state of the Indonesian people. The points of Pancasila are in line with Islamic values. It fits the points of the Jakarta Charter which acknowledged God Almighty. Jasmin, a woman, who has been active in the Tabligh Council of the Islamic

${ }^{19}$ Andreas M Kaplan and Michael Haenlein, “Users of the World, Unite! The Challenges and Opportunities of Social Media," Business Horizons 53, no. 1 (2010): 59-68, https://doi.org/10.1016/j.bushor.2009.09.003.

20 Anne Linke and Ansgar Zerfass, "Social Media Governance: Regulatory Frameworks for Successful Online Communications," Journal of Communication Management, 2013.

${ }^{21}$ Christian Fuchs, Social Media: A Critical Introduction (Sage, 2017).

${ }^{22}$ Kaplan and Haenlein, "Users of the World, Unite! The Challenges and Opportunities of Social Media."

23 J.O Gilliot, Cl., Repp, R.C., Nizami, K.A., Hooker, M.B., Lin, Chang-Kuan and Hunwick, "' 'Ulamā”, in: Encyclopaedia of Islam" (Brill, 2020), http:/ / dx.doi.org/10.1163/15733912_islam_COM_1278.

${ }^{24}$ Mansur, interview (28 th of January 2021). 
organization, Muhammadiyah, revealed the compatibility between Islam and Pancasila.25 Pancasila, as the foundation of the Indonesian state created by the founding fathers, has accommodated religious interests, including Islam. ${ }^{26}$ The Islamic organization, Muhammadiyah, believes that Pancasila is not a religion, but its principles are in line with Islam. ${ }^{27}$ Muhammadiyah is also responsible for maintaining the Indonesian state with the principles of Pancasila. 28

Furthermore, Wasi, an Islamic scholar from the Islamic organization of Majelis Tafsir Alquran, revealed that Indonesia is not an Islamic state. Indonesia is established based on the 1945 Constitution with the motto Unity in Diversity. Expressing different aspirations also needs to be shown in the right way, such as disagreements with a leader or when an existing leader deviates. ${ }^{29}$

It can be seen from this that Muslim male and female Islamic experts from various Islamic groups believe that Pancasila, the Indonesian state's philosophy, is highly important to comprehend and acknowledge since it is in harmony with Islam.

\section{Spirit of Nationalism}

Nationalism as a national spirit is another dimension that needs to be built in strengthening awareness of being a person who loves Indonesia. The spirit of nationalism can be cultivated through cultural development. In other research, it was also found the importance of instilling a spirit of nationalism in Islamic educational institutions. ${ }^{30}$ Kamil, as a member of the Tabligh Council of Islamic organizations, Muhammadiyah, expressed the importance of cultivating nationalism through puppet cultural performances. ${ }^{31}$

National understanding is important as a unifier of differences. The nationalism that occurred in Indonesia could be an example for other countries, especially countries in the Middle East which were divided by the Arab Spring. ${ }^{32}$ Therefore, it can be concluded that nationalism and love for the nation itself are important points that should always be considered to fight religious radicalism.

\section{Islam as Values, not as a System}

Some groups who are members of radical Islamic organizations often aspire to the establishment of the Indonesian state to become an Islamic state. Implementing Islamic values such as the value of peace and justice is more valuable than changing the state system. This opinion was expressed by Karim, an Islamic scholar from the Islamic organization, Nahdlatul Ulama. ${ }^{33}$

Furthermore, some Indonesians also think that Indonesia is a country that is taghut, denoting a focus of worship other than God (Allah). This assumption was

${ }^{25}$ Jasmin, interview (31 ${ }^{\text {st }}$ of January 2021).

26 Pasha, interview (5 $5^{\text {th }}$ of February 2021).

${ }^{27}$ Muhamad Ali, “The Muhammadiyah's 47th Congress and 'Islam Berkemajuan,'” Studia Islamika 22, no. 2 (2015): 377-86.

${ }^{28}$ Hasnan Bachtiar, "Dār Al-'Ahd Wa Al-Shahādah: Muhammadiyah's Position and Thoughts on Negara Pancasila," Studia Islamika 27, no. 3 (2020): 485-513.

29 Wasi, interview (14 $4^{\text {th }}$ of January 2021).

${ }^{30}$ M Nurul Ikhsan Saleh et al., "Islamic Boarding School and the Deradicalization Efforts of Islamic Education in Madura," Jurnal Pendidikan Islam 8, no. 2 (2019): 259-86, https://doi.org/10.14421/jpi.2019.82.259-286.

${ }^{31}$ Kamil, interview (13 ${ }^{\text {th }}$ of January 2021).

${ }^{32}$ Mansur, interview (28 th of January 2021).

${ }^{33}$ Karim, interview (15 th of Januari 2021). 
denied by Islamic scholars from the Islamic organization, Nahdlatul Ulama, who said that Indonesia is under the teachings of the Quran. In other words, Indonesia is not a taghut country. ${ }^{34}$

In conclusion, Islam can be applied in Indonesia by prioritizing its values. Islam is implemented not only by changing its democratic system into an Islamic state, but it is also in line with the Quran so that Indonesia is not a country of taghut or shows a focus of worship other than God.

\section{Caliphate, Not the Solution}

The aspiration to change Indonesia's democratic system with a caliphate system is not the right answer to solving the problems faced by Indonesia today. One of the reasons is that the implementation of the Caliphate system in the past was a part of historical compulsions. ${ }^{35}$

The implementation of the democratic system in Indonesia is currently better than the application of the Caliphate system in the past because the Caliphate system at that time did not have a controlling institution so there was a tendency for corruption. Moreover, the enforcement of the Caliphate still tends to be seen as based on violence. In fact, the two major Islamic organizations in Indonesia, such as Muhammadiyah and Nahdlatul Ulama, reject various forms of violence. Mansur, an Islamic scholar of Nahdlatul Ulama, argues that the Caliphate is not a superior system to the existing system in Indonesia at this time. ${ }^{36}$

What needs to be anticipated is the spread of the Caliphate in schools or even avoiding preachers in Islamic institutions who support the implementation of the Caliphate. One example stated by one participant was the existence of Caliphate books that infiltrated schools in Indonesia. ${ }^{37}$

\section{The other example was}

In a university such as State Islamic University (UIN) of Sunan Kalijaga, it was found that one student was waving the Caliphate flag. This should also be a concern for universities to fight against religious radicalism. An Islamic figure from Nahdlatul Ulama said that the Indonesian government had failed in fostering society. At the State Islamic University (UIN) of Sunan Kalijaga, the Caliphate flag appeared, and then some female students raised the Caliphate flag. ${ }^{38}$

The discourse of a caliphate in Indonesia has emerged along with the presence of the Hizbut Tahrir Indonesia (HTI) Organization. ${ }^{39}$ From one point of view, the HTI organization did not threaten Indonesia because it did not physically destroy it. However, this organization was considered deviant because it wanted to change Indonesia as a country with the Caliphate system. This was expressed by Husain as a member of the Education Council at the Islamic organization, Muhammadiyah.

During the demonstration, members of the HTI organization did not destroy anything, but they belonged to the radical group because they wanted to change the

${ }^{34}$ Mansur, interview (28 ${ }^{\text {th }}$ of January 2021).

${ }^{35}$ Mansur, interview (28 January 2021).

${ }^{36}$ Mansur, interview (28 January 2021).

${ }^{37}$ Mansur, interview (28 January 2021).

${ }^{38}$ Mansur, interview (28 January 2021)

${ }_{39} \mathrm{M}$ Djidin and Sahiron Syamsuddin, "Indonesian Interpretation of the Qur'an on Khilāfah: The Case of Quraish Shihab and Yudian Wahyudi on Qur'an, 2: 30-38," Al-Jami'ah: Journal of Islamic Studies 57, no. 1 (2019): 143-66. 
structure from the Unitary State of the Republic of Indonesia to a Caliphate state. 40

Another participant, Jamal who is also active in the Islamic organization, Muhammadiyah, has a different opinion where he said that the HTI and Salafi organizations were not completely wrong, but their weakness lied in the lack of morals in respecting others. ${ }^{41}$ Furthermore, one of the participants, Iqbal almost agreed with the previous participants who defended the HTI organization. He said that the desire to change the state system with Caliphate was not the desire of everyone in the HTI organization so that it could not be generalized. ${ }^{42}$

From the above discussion, it can be concluded that the aspiration to make Indonesia with the Caliphate system is a threat to Indonesia. The education sector, such as schools and tertiary institutions, needs to be supervised by the government to continue to support the integrity of the Unitary Republic of Indonesia and reject the Caliphate system. Although, on the one hand, many people perceive the HTI organization as a deviating organization that supports the Caliphate system, there are still some Islamic scholars who said that the Islamic organization HTI was on the right path, because not everyone in the organization wanted to implement the Caliphate system.

\section{Promoting Inclusive Approaches as a Soft-Approach to Tackle Radicalization}

The second theme in the deradicalization of religion is to put forward a soft approach, namely an inclusive approach where everyone does not feel the most correct person in expressing opinions. The soft method differs from the hard approach in that it promotes military initiatives that are judged unsuccessful according to Yaoren's study. ${ }^{43}$ One of the inclusive approaches is to have an inclusive attitude, which was mentioned by one of the participants who had been the central committee of the Islamic organization, Muhammadiyah. ${ }^{44}$ This inclusive approach can at least be classified as a soft approach. The soft approach is considered by one of the participants to be the most appropriate approach to the deradicalization process compared to the military approach that is now often practiced in Indonesia. ${ }^{45}$

Moreover, the approach taken by The National Counter-Terrorism Agency (BNPT) in Indonesia is considered not neutral because it is considered to have funding support from other countries such as Australia. ${ }^{46}$

Following are specific efforts that can be made in promoting an inclusive approach, including the Islamic wasathiyah approach, tolerance, dialogue, logical Islam, and against stigma.

\section{Islamic Wasathiyah (Islamic Moderation)}

\footnotetext{
40 Husain, interview (8 February 2021).

41 Jamal, interview (14 January 2021).

42 Iqbal, interview (31 January 2021).

43 Yaoren, "Leadership Decapitation and the Impact on Terrorist Groups."

44 Jasmin, interview (31 January 2021).

${ }^{45}$ Rania, interview (3 February 2021).

46 Jamal, interview (14 January 2021).
} 
Wasathiyah means moderation or is the middle way. ${ }^{47}$ Becoming an Islamic scholar amid society needs to prioritize the Islamic wasathiyah approach, which is to be in the middle or not to be extreme, especially in conduct. In the deradicalization program, religion, one of which is Islam, cannot be excluded. There will be a lot more radicalism if religion isn't taken into account. The important thing is to reform religious understanding and strengthen religious leaders to become Islamic scholars who can promote and support peace. ${ }^{48}$ One of the participants from the Islamic group, Nahdlatul Ulama, who heads a pesantren in Yogyakarta, stressed the need of fostering Islamic wasathiyah for Muslim scholars. ${ }^{49}$

This is almost the same as the previous participant's statement, one of the participants affiliated with the Islamic organization, Muhammadiyah, said that the Aisyiyah organization as the basis for women's organizations in Muhammadiyah circles also supports Islamic wasathiyah values. ${ }^{50}$ Islamic wasathiyah aims to fight against the notion of religious radicalism in Indonesia, especially among women. ${ }^{51}$

Islamic wasathiyah is an attitude and understanding towards religion that is not extreme both to the right and the left. One participant said that Islamic wasathiyah means being in the middle position in understanding religion. ${ }^{52}$

From the above discussion, Islamic wasathiyah can be a soft approach in the deradicalization of religion. Islamic wasathiyah emphasizes moderate, tolerant, and mutual understanding.

\section{2. $\quad$ Tolerance}

The next soft approach in fighting religious radicalism is an emphasis on tolerance in religion. Even though there are a variety of different religious backgrounds, a Muslim should tolerate one another. One of the actions in fostering tolerance is to aggressively promote the values of inclusion, tolerance, and modernization using social media. ${ }^{3}$

The way to tolerate this is by realizing that religious understandings are very diverse. This requires maturity in interpreting religious texts. It is important to teach the variations in the interpretation of the text or figh. If religious radical groups are using religious texts for acts of violence, a religious leader can justify or counter incorrect understandings or arguments against the interpretation of these religious texts. ${ }^{54}$ One of the figures in the Islamic organization, Muhammadiyah, Rani revealed the importance of teaching several streams in interpreting religious texts so that people accept these differences. ${ }^{55}$ Another study found that the tolerance values can also be found in local wisdom such as nemui nyimah which is relevant to the religious

\footnotetext{
47 Wan Kamal Mujani, Ermy Azziaty Rozali, and Nor Jamaniah Zakaria, “The Wasatiyyah (Moderation) Concept: Its Implementation in Malaysia," Mediterranean Journal of Social Sciences 6, no. 4 (2015): 66.

48 Rached Ghannouchi, "Deradicalization Through Religious Education," Routledge Handbook of Deradicalisation and Disengagement, 2020, 44.

${ }^{49}$ Karim, interview (15 Januari 2021).

${ }^{50}$ Rania, interview (3 February 2021).

${ }^{51}$ Rania, interview (3 February 2021).

52 Rania, interview (3 February 2021).

53 Rania, interview (3 February 2021).

54 Ghannouchi, "Deradicalization Through Religious Education."

55 Rania, interview (3 February 2021).
} 
understanding. 56

Tolerance must be instilled in students starting at the elementary school level, i.e. Kindergarten. Children in kindergarten are not taught to distinguish between Muslims and non-Muslims because it will result in gaps and distances among them. ${ }^{57}$

To summarize, tolerance is a critical component of religious deradicalization, since tolerance may serve as a basis for comprehending differences. This tolerant mindset must be instilled in children from an early age.

\section{Dialogue}

The third inclusive soft approach is to promote dialogue that involves all groups. One of the participants, Kamil from the Islamic organization Muhammadiyah, complained that the recent experiences of national dialogue related to radicalism did not involve opposition organizations from the government. From this approach, the dialogue that was established did not involve a wider variety of Islamic religious organizations, especially from groups of religious organizations that are considered to be associated with radical organizational networks. This is important to collaborate with all levels of religious organizations that have different views. ${ }^{58}$ Dialogue can be a part of bringing together differences of opinion between groups. The Prophet Muhammad himself taught not to consider his opinion to be the most correct one which then made other opinions wrong. ${ }^{59}$

Therefore, dialogue is one approach that can be used as a soft approach in the deradicalization of religion.

\section{Islam as a Logical Religion}

One of the concerns of participants in the process of religious deradicalization is how to build awareness that Islam itself is a logical religion in which one needs common sense in interpreting religious texts. This was revealed by one of the participants from the Islamic organization, Hizbut Tahir Indonesia.

Islam is a logical religion, a religion under human nature. ${ }^{60}$ One example of the logic of religious thinking that can be used is the principle of sharing. A Muslim should be able to collaborate with others who embrace different religious beliefs than he does. ${ }^{6}$

Therefore, interpreting the holy verses of the Quran requires logical thinking. When understanding jihad by carrying out acts of terrorism through killing innocent people, that person has put aside the logic of thinking about humanity.

\section{Eliminating Stigma}

Another effort that can be taken in a soft approach to deradicalization of religion is to avoid behaviors that create a negative stigma against other groups. One example,

${ }^{56}$ Muhammad Candra Syahputra and Idrus Ruslan, “Nemui Nyimah: Lampung Local Wisdom with Religious Moderation Insight," AKADEMIKA: Jurnal Pemikiran Islam 26, no. 1 (2021): 59-74.

${ }^{57}$ Rania, interview (3 $3^{\text {rd }}$ of February 2021).

${ }^{58}$ Kamil, interview (13 th of January 2021).

${ }^{59}$ Jamal, interview (14 ${ }^{\text {th }}$ of January 2021).

${ }^{60}$ Maryam, interview (16 $6^{\text {th }}$ of February 2021).

${ }^{61}$ Mansur, interview (28 th of January 2021). 
Salafi groups in some cases stigmatize certain traditions as heresy. ${ }^{62}$ It is expected that neither the government nor the ulama would stigmatize other Muslim scholars, causing conflicts among religious leaders, particularly Muslim figures. Kamil, one of the participants, emphasized the necessity of behavior in Islamic educational institutions to not stigmatize other Muslim scholars. ${ }^{63}$

Recently, Muslim scholars at Islamic boarding school (henceforth: pesantren) have often been accused of cases of religious radicalism. There was stigmatization in certain circumstances. Pesantren, on the other hand, has made significant contributions to Indonesia's peacekeeping efforts. According to another study, in a democratic government such as Indonesia today, there are chances for rivalry and public debate to eliminate other groups. ${ }^{64}$ One of these methods of extermination is to stigmatize other groups. One of the participants expressed that this activity would be associated with a negative stigma since it would be the complete antithesis of attempts to deradicalize religion. ${ }^{65}$

The findings above show that those attempting to deradicalize religion must be careful not to fall into the trap of imposing a negative stigma on those who disagree or criticize.

\section{Promoting in-Depth Understandings of Islam}

The third theme in this study focuses on the deradicalization of religion which promotes a deeper understanding of Islam. Among the approaches in providing this in-depth understanding are providing a humanistic and accommodating understanding of Islamic history, understanding the sources of religion comprehensively, certifying Islamic preachers, and developing dynamic mosque managers.

\section{A Humanistic and Accommodating Understanding of Islamic History}

Understanding history including the history of Islam is among the steps to promote a deeper understanding of Islam. This phase helps religious believers avoid a shallow knowledge that might lead to misguided or even extreme religious beliefs. For example, in understanding verses about jihad, it is not enough to use sections and parts of the Quran or Hadith to comprehend texts on jihad.66 One example of the history of the development of Islam in Indonesia is how Walisongo taught Islam in a humanistic and accommodating way. In this approach, Islamic scholars or Muslims who are interested in the history of Islam will be able to teach Islam peacefully. ${ }^{67}$

Indonesian people who think that Indonesia is not in accordance with Islam mean that they do not understand the history of the founding of Indonesia. ${ }^{68}$ People who have an extreme religious perspective are referred to as a group that has limited

62 Achmad Zainal Arifin, "Defending Traditions, Countering Intolerant Ideologies: ReEnergizing the Role of Modin in Modern Java," Al-Jami'ah: Journal of Islamic Studies 55, no. 2 (2017): 265-92.

63 Kamil, interview (13 th of January 2021).

64 Ali Muhammad and Eric Hiariej, "Deradicalization Program in Indonesia Radicalizing

the Radicals," Cogent Social Sciences 7, no. 1 (2021): 1905219, https://doi.org/10.1080/23311886.2021.1905219.

${ }^{65}$ Kamil, interview (13 $3^{\text {th }}$ of January 2021).

${ }^{66}$ Rania, interview ( $3^{\text {th }}$ of February 2021).

${ }^{67}$ Iqbal, interview (31 $1^{\text {st }}$ of January 2021).

${ }^{68}$ Munsif, interview (13 $3^{\text {th }}$ of January 2021). 
comprehension of Islam and Indonesia. ${ }^{69}$

The participants indicated that certain people's radical understanding is caused by a lack of understanding of the history of Islam, the history of Islam in Indonesia, and their lack of knowledge.

\section{Understanding Religious Sources Comprehensively}

One of the other efforts in countering religious radicalism is to understand the sources of religion comprehensively. Islamic scholars are expected to be able to understand and provide a complete and comprehensive understanding of Islam without limiting it to one particular thought. The participant from the Hizbut Tahir Indonesia organization revealed the importance of understanding religion in its entirety. ${ }^{70}$ In addition, religious lecturers should also understand the meaning of the Qur'anic verse in-depth, which is not only based on the understanding that conveys even one verse. This is an attempt to avoid misunderstandings. ${ }^{71}$ The Muslim community needs to understand religious texts dynamically and prospectively. ${ }^{72}$

This is also important to provide an understanding of religion from several different perspectives. Society needs to be taught from several different madhhabs such as in the case of Figh. In the study of Figh, people can be taught differences of opinion from many madzhab (thoughts), such as the Maliki, Hanafi, and Shafi'e's thought which can provide complete knowledge of various madhhabs. ${ }^{73}$ One of the participants mentioned the significance of thoroughly understanding religion as another component in the quest to deradicalize religion. Although it is acknowledged that some people have a profound understanding of religion but then exploit it for political purposes. ${ }^{74}$

As it can be seen from the previous statement, promoting a thorough study of religious sources is a mission that must be prioritized in the de-radicalization of religion.

\section{Certification of Religious Lecturers}

Another idea that emerged regarding the deradicalization of religion was related to the importance of the certification of lecturers. Lecturers, especially Islamic preachers, need to be considered by evaluating their competencies. Lecturer certification credentials have become prominent and urgent. ${ }^{75}$ Another participant compared those religious preachers such as in Christianity, Catholicism, and Buddhism that require certification or training. Therefore, Islamic preachers also need to be trained very strictly to avoid incompetent clerics. ${ }^{76}$ Gus Miftah, Gus Baha, and Gus Muwafiq are among the young Islamic preachers recommended by Nahdlatul Ulama figures, according to the participants..$^{77}$

As an official religious institution supported by the Indonesian government, the

${ }^{69}$ Karim, interview (15 ${ }^{\text {th }}$ of Januari 2021).

${ }^{70}$ Maryam, interview (16 ${ }^{\text {th }}$ of February 2021).

${ }^{71}$ Jasmin, interview (31 ${ }^{\text {st }}$ of January 2021).

72 Widhiya Ninsiana, "Deradicalizing Religious Extremism Linguistically: An Intertextual Approach To Islamic Extremists' View on The Qur'anic Interpretation," Akademika : Jurnal Pemikiran Islam 25, no. 2 (2020): 277-94.

${ }^{73}$ Jamal, interview (14 ${ }^{\text {th }}$ of January 2021).

${ }^{74}$ Munsif, interview (13 th of January 2021).

${ }^{75}$ Mansur, interview (28 th of January 2021).

${ }^{76}$ Rania, interview (3rd of February 2021).

${ }_{77}$ Mansur, interview (28 th of January 2021). 
Indonesian Ulama Council (MUI) must also contribute to reporting and offering knowledge of what is extreme and what is not so that people might comprehend. ${ }^{78}$ It's also worth noting that anyone interested in learning more about Islam should consult with Islamic experts to prevent misunderstandings. ${ }^{79}$

The certification of Islamic lecturers is a critical issue that must be addressed. At the very least, religious lecturers' competency, particularly in Islam, can be regarded. The Indonesian Ulema Council also has a significant role to play in issuing fatwas regarding what is right and wrong.

\section{Dynamic Mosque Manager}

The mosque as a venue for learning about Islam is critical to the deradicalization of religion. Mosque management must pay attention so that the lectures given are in keeping with the spirit of developing Indonesia, rather than advocating for Indonesia to become an Islamic state. ${ }^{80}$ The participant stated that numerous mosques in Yogyakarta, such as UGM and UPN, are gradually becoming exclusive, where particular organizations dominate them and do not allow other Islamic groups to offer lectures, even though the mosques were indeed inclusive. ${ }^{81}$

According to the preceding statement, an Islamic expert mentioned that certain mosques only allow lecturers from specific groups to preach. This may run counter to Islamic norms, which demand that mosques accept all Islamic organizations, particularly inclusive Islamic groupings.

\section{E. Utilizing Social Media}

Efforts to deradicalize religion require the use of social media. Social media can be a strategy to resist radicalism, counter hate speech and minimize blind spots for radicalism.

\section{Social Media as a Means of Resistance}

Social media has the potential to be a means of deradicalization where many people currently use it. Many young people follow social media accounts of religious figures. Social media can be effective because the messages conveyed can be more organized. ${ }^{82}$ Social media may also be used to combat websites that spread religious radicalism-related content. 83

According to participants' opinions, in 2015, the number of Islamic websites associated with religious extremism was significantly bigger than the number of moderately regulated Islamic websites, with 900 radical Islamic websites and just 100 moderate Islamic websites. According to one survey, there were 6,000 websites assessed to support extreme groups throughout the world in 2007.84 However, caution must be given when censoring websites that are labeled radical, because not every information on the website is radical. ${ }^{85}$

One participant hopes that the current war on religious deradicalization needs to be carried out through social media. The hope is that radical news does not

\footnotetext{
78 Diwan, interview (10 ${ }^{\text {th }}$ of February 2021).

${ }^{79}$ Maryam, interview (16 $6^{\text {th }}$ of February 2021$)$.

${ }^{80}$ Mansur, interview (28 th of January 2021).

${ }^{81}$ Mansur, interview (28th of January 2021).

${ }^{82}$ Kamil, interview (13 ${ }^{\text {th }}$ of January 2021).

${ }^{83}$ Mansur, interview (28 $8^{\text {th }}$ of January 2021).

84 Weimann, Terror on the Internet: The New Arena, the New Challenges.

${ }^{85}$ Mansur, interview (28 th of January 2021).
} 
dominate news searchers like Google. There is a need for a more widespread propagation of Islam through social media, where Islam serves the collective good. ${ }^{86}$

Social media can be a means of resistance to fight news on websites that display radical information. Islamic news that is beneficial needs to be further improved on social media.

\section{Countering Hate Speech on Social Media}

The approach to deradicalization of religion can also be taken by fighting hate speech on social media where hate speech is commonplace on the internet. ${ }^{87}$ One participant said that the comments of social media users were very worrying in terms of hate speech that led to divisions between groups and fights. ${ }^{88}$ Provocation and hate speech are considered to be common on social media. As a result, social media platforms such as Facebook, YouTube, and WhatsApp group apps may be used to combat cyberbullying. ${ }^{89}$

One of the tasks in deradicalization through social media is to demonstrate how social media is utilized as a unifier rather than a divider amongst religious organizations, particularly Islamic organizations. One participant expressed concern about the use of social media in Indonesia, where it is being used to foment hatred amongst Islamic organizations..$^{90}$

On the one hand, social media may be used to disseminate hate speech, but it also has the potential to be used to deradicalize religion, such as by posting messages on Facebook, Youtube, and WhatsApp. The use of social media to convey the notion of mutual tolerance for diversity and solidarity for all groups is one option to do.

\section{Minimizing Blind Spot Areas of Radicalisation}

The spread of radicalism is also in the blind spot area. One participant said that in the world of higher education there are still blind spot areas that have the potential to be infiltrated by radicalism, especially in the departments of medicine, engineering, and pharmacy. ${ }^{91}$

One of the deradicalization steps to fill the blind spot area against radicalism can be implemented through promoting the use of social media such as Youtube, Twitter, Facebook, and Instagram. Social media itself on the other hand is also used as a medium by terrorists in spreading radical ideas. Therefore, social media can also be used as a means to counter radicalism. Islamic scholars need to be involved in it by writing messages of kindness on social media. ${ }^{92}$ The idea of using social media was also strengthened by the participants where Facebook, Youtube, and Instagram can be used as a medium for doing $d a^{\prime} w a h$ which is compatible with the young generation. ${ }^{93}$ Deradicalization can also be implemented by distributing short videos about peace. ${ }^{94}$ Furthermore, another participant from the Muhammadiyah organization stated that in the framework of counter-radicalism, da'wah through digital media should be

${ }^{86}$ Karim, interview (15 $5^{\text {th }}$ of January 2021).

87 Haedar Nashir et al., "Muhammadiyah's Moderation Stance in the 2019 General

Election: Critical Views from Within," Al-Jami'ah: Journal of Islamic Studies 57, no. 1 (2019): 1-24.

88 Maryam, interview (16 $6^{\text {th }}$ of February 2021).

${ }^{89}$ Maryam, interview (16 ${ }^{\text {th }}$ of February 2021$)$.

90 Jamal, interview (14 ${ }^{\text {th }}$ of January 2021).

${ }^{91}$ Mansur, interview (28 th of January 2021).

92 Karim, interview (15 ${ }^{\text {th }}$ of Januari 2021).

${ }_{93}$ Maryam, interview (16 $6^{\text {th }}$ of February 2021).

94 Pasha, interview (5 $5^{\text {th }}$ of February 2021). 
supported. One of the strategies is to employ traditional forms of entertainment, such as wayang tales, to promote nationalism. ${ }^{95}$

Dissemination of information and $d a^{\prime} w a h$ for peace and nationalism can be done through social media. One of the objectives of disseminating such information is to counter the spread of religious radicalism in blind spot areas in certain universities and communities. These deradicalization efforts also need to involve youth who love peace and non-violence. ${ }^{96}$

\section{F. Conclusion}

This study answers a research question about the perceptions of Islamic scholars in Yogyakarta regarding the deradicalization of religion and the roles of social media in religious deradicalization. There are four main themes in the findings of this study related to the perceptions of Islamic scholars on religious deradicalization and the role of social media; Firstly, the importance to increase consciousness of being Indonesian through comprehending the harmony between Pancasila and Islam, the spirit of nationalism, the knowledge of Islam as ideals rather than a system, and the understanding of the caliphate not as a solution; Secondly, building an inclusive approach as a soft approach to tackle radicalization, which includes the Islamic wasathiyah approach, tolerance, dialogue, logical religious Islam, stopping stigmatizing attitudes; Thirdly, promoting a deep understanding of Islam, which consists of a humanistic and accommodating understanding of Islamic history, a comprehensive understanding of religious sources, certification of lecturers, and dynamic mosque management.; Fourthly, taking advantage of social media, which covers social media as a means of resistance to counter hate speech on social media, and minimize blind spot areas of radicalization such as those in medical, pharmacy, and engineering study programs at Indonesian universities.

This research has implications for deradicalization efforts which should not be separated from efforts to build nationalism or love for Indonesia and the process of deradicalization needs to be focused on a soft approach. Furthermore, this study contributes to how Islamic scholars should mainstream the study of religious deradicalization to increase people's awareness and pride in being Indonesian, prioritizing an inclusive approach, mastery of deep Islamic sources, and the use of social media to combat radicalism. These efforts also need attention from the government, religious leaders, educational institutions, and the BNPT in the religious deradicalization program. Another effort is to ensure that mosques are not controlled by radical groups and to remove blind spots in tertiary institutions that are vulnerable to the spread of radicalism. The study's weakness is that the existing participants are still dominated by Islamic groups like Muhammadiyah and Nahdlatul Ulama, and there is still a shortage of responders from Salafi and Tarbiyah organizations. As a result, future studies should include Islamic scholars from anti-government Islamic organizations, in other words, from the opposition group. This aims to give a more complete view of the findings of religious deradicalization research, as well as the significance of social media in religious deradicalization

${ }^{95}$ Kamil, interview (13 ${ }^{\text {th }}$ of January 2021).

96 Zulfan Taufik, "From Negative To Positive Peace: Strengthening The Role of Youth in Religious Peacebuilding in Bukittinggi, West Sumatra," Akademika : Jurnal Pemikiran Islam 25, no. 2 (2020): 257-76.ta 


\section{G. Acknowledgments}

No potential conflict of interest was reported by the researchers. The researchers would like to thank the Directorate of Research and Community Service, Universitas Islam Indonesia, for funding this research with the contract number 004/Dir/DPPM/70/Pen.Pemula/II/2020.

\section{H. Author Contributions Statement}

MNIS led, conceptualized, and designed the project. MNIS prepared, cleaned the data, and wrote the intoduction, findings, and discussion. YA added some information and edited the manuscript[.]

\section{REFERENCES}

Al-Shishani, Murad Batal. "Taking Al-Qaeda's Jihad to Facebook." The Jamestown Foundation: Terrorism Monitor 8, no. 5 (2010): 3.

Ali, Muhamad. "The Muhammadiyah's 47th Congress and 'Islam Berkemajuan.'” Studia Islamika 22, no. 2 (2015): 377-86.

Altier, Mary Beth, Christian N Thoroughgood, and John G Horgan. "Turning Away from Terrorism: Lessons from Psychology, Sociology, and Criminology." Journal of Peace Research 51, no. 5 (2014): 647-61. https:// doi.org/10.1177/0022343314535946.

Arifianto, Alexander Raymond. "Islam Nusantara: NU's Bid to Promote 'Moderate Indonesian Islam,'” 2016.

Arifin, Achmad Zainal. "Defending Traditions, Countering Intolerant Ideologies: ReEnergizing the Role of Modin in Modern Java." Al-Jami'ah: Journal of Islamic Studies 55, no. 2 (2017): 265-92.

Bachtiar, Hasnan. "Dār Al-'Ahd Wa Al-Shahādah: Muhammadiyah's Position and Thoughts on Negara Pancasila." Studia Islamika 27, no. 3 (2020): 485-513.

Bjørgo, Tore. "Dreams and Disillusionment: Engagement in and Disengagement from Militant Extremist Groups." Crime, Law and Social Change 55, no. 4 (2011): 277-85. https://link.springer.com/article/10.1007/s10611-011-9282-9.

Braun, Virginia, and Victoria Clarke. "Using Thematic Analysis in Psychology." Qualitative Research in Psychology 3, no. 2 (2006): 77-101.

Dean, Geoff, and Peter Bell. "The Dark Side of Social Media: Review of Online Terrorism." Pakistan Journal of Criminology 3, no. 4 (2012): 191-210. https://eprints.qut.edu.au/50162/.

Djidin, M, and Sahiron Syamsuddin. "Indonesian Interpretation of the Qur'an on Khilāfah: The Case of Quraish Shihab and Yudian Wahyudi on Qur'an, 2: 30-38." Al-Jami'ah: Journal of Islamic Studies 57, no. 1 (2019): 143-66.

Doosje, Bertjan, Fathali M Moghaddam, Arie W Kruglanski, Arjan De Wolf, Liesbeth Mann, and Allard R Feddes. "Terrorism, Radicalization and de-Radicalization." $\begin{array}{lllll}\text { Current Opinion in } & \end{array}$ https:// doi.org/10.1016/j.copsyc.2016.06.008.

Farida, Umma, and Abdurrohman Kasdi. "The 2017 KUPI Congress and Indonesian Female ‘Ulama." Journal of Indonesian Islam (JIIS) 12, no. 02 (2018): 135-58.

Fuchs, Christian. Social Media: A Critical Introduction. Sage, 2017.

Ghannouchi, Rached. "Deradicalization Through Religious Education." Routledge Handbook of Deradicalisation and Disengagement, 2020, 44.

Gilliot, Cl., Repp, R.C., Nizami, K.A., Hooker, M.B., Lin, Chang-Kuan and Hunwick, 
J.O. "'Ulamā", in Encyclopaedia of Islam." Brill, 2020. http://dx.doi.org/10.1163/1573-3912_islam_COM_1278.

Harrison, Helena, Melanie Birks, Richard Franklin, and Jane Mills. "Case Study Research: Foundations and Methodological Orientations." In Forum Qualitative Sozialforschung/Forum: Qualitative Social Research, Vol. 18, 2017.

Horgan, John, and Kurt Braddock. "Rehabilitating the Terrorists?: Challenges in Assessing the Effectiveness of de-Radicalization Programs." Terrorism and $\begin{array}{llllll}\text { Political Violence 22, no. } 2 & \text { (2010): }\end{array}$ https:// doi.org/10.1080/09546551003594748.

Kaplan, Andreas M, and Michael Haenlein. "Users of the World, Unite! The Challenges and Opportunities of Social Media." Business Horizons 53, no. 1 (2010): 59-68. https://doi.org/10.1016/j.bushor.2009.09.003.

Latief, Hilman, and Haedar Nashir. "Local Dynamics and Global Engagements of the Islamic Modernist Movement in Contemporary Indonesia: The Case of Muhammadiyah (2000-2020)." Journal of Current Southeast Asian Affairs, 2020, 1868103420910514. https:// doi.org/10.1177/1868103420910514.

Linke, Anne, and Ansgar Zerfass. "Social Media Governance: Regulatory Frameworks for Successful Online Communications." Journal of Communication Management, 2013.

Lubis, Halimah. "Model Dakwah LDII Yogyakarta Dalam Penguatan Kerukunan Umat Beragama (Ditinjau Dari Perspektif Manajemen Dakwah)." Tadbir: Jurnal Manajemen Dakwah FDIK IAIN Padangsidimpuan 2, no. 1 (2020): 23-48.

Muhammad, Ali, and Eric Hiariej. "Deradicalization Program in Indonesia Radicalizing the Radicals." Cogent Social Sciences 7, no. 1 (2021): 1905219. https:// doi.org/10.1080/23311886.2021.1905219.

Mujani, Wan Kamal, Ermy Azziaty Rozali, and Nor Jamaniah Zakaria. "The Wasatiyyah (Moderation) Concept: Its Implementation in Malaysia." Mediterranean Journal of Social Sciences 6, no. 4 (2015): 66.

Nashir, Haedar, Zuly Qodir, Achmad Nurmandi, Hasse Jubba, and Mega Hidayati. "Muhammadiyah's Moderation Stance in the 2019 General Election: Critical Views from Within." Al-Jami'ah: Journal of Islamic Studies 57, no. 1 (2019): 1-24.

Ninsiana, Widhiya. "Deradicalizing Religious Extremism Linguistically: An Intertextual Approach To Islamic Extremists' View on The Qur'anic Interpretation." Akademika : Jurnal Pemikiran Islam 25, no. 2 (2020): 277-94.

Saleh, M Nurul Ikhsan, Burhan Nudin, Khusaini Khusaini, Puji Alim, and Ida Ayu Putri. "Islamic Boarding School and the Deradicalization Efforts of Islamic Education in Madura." Jurnal Pendidikan Islam 8, no. 2 (2019): 259-86. https:// doi.org/10.14421/jpi.2019.82.259-286.

Setiawan, Adib Rifqi. "Islamic Education in Southeast Asia," 2020. https://edarxiv.org/dnjqv/.

Syahputra, Muhammad Candra, and Idrus Ruslan. "Nemui Nyimah: Lampung Local Wisdom with Religious Moderation Insight." Akademika : Jurnal Pemikiran Islam 26, no. 1 (2021): 59-74.

Taufik, Zulfan. "From Negative To Positive Peace: Strengthening The Role of Youth in Religious Peacebuilding in Bukittinggi, West Sumatra." Akademika : Jurnal Pemikiran Islam 25, no. 2 (2020): 257-76.

Tsesis, Alexander. "Social Media Accountability for Terrorist Propaganda." Fordham L. Rev. 86 (2017): 605.

Weimann, Gabriel. Terror on the Internet: The New Arena, the New Challenges. US Institute of Peace Press, 2006. 
Yaoren, Kenneth Yeo. "Leadership Decapitation and the Impact on Terrorist Groups." Counter Terrorist Trends and Analyses 11, no. 3 (2019): 7-12.

Yin, Robert K. "Case Study Research and Applications." Sage, 2018. http://dln.jaipuria.ac.in:8080/jspui/bitstream/123456789/1615/1/case study research and applications design and methods by campbell $\% 2 \mathrm{c}$ donald thomas yin $\% 2$ c robert k..pdf. 